\title{
Effect of diet on live weight and egg weight of backyard hens during the rainy season
}

\author{
JN Barocio-Urue ${ }^{a}$, A Juárez-Caratachea ${ }^{*}$, E Gutiérrez-Vázquez ${ }^{a}$, \\ RE Pérez- Sánchez ${ }^{\mathrm{c}}$, R Ortiz-Rodríguez
}

\begin{abstract}
The objective was to determine the effect of diet on live weight (LW) and egg weight (EW) of backyard hens (BH) during the rainy season in the Bajío region of the state of Michoacán, Mexico. Seventeen municipalities were sampled, where 101 BH (six hens/municipality) were captured and weighed and $101 \mathrm{eggs}$ (six eggs/municipality) were harvested and weighed. The crops of the captured hens were removed Post-sacrifice, the organic content/crop (OCC) was classified and weighed by components, to later perform chemical compositional analysis. Data were analysed using generalised linear models and the differences between municipalities were obtained by the method of least squares means. The weight of the OCC $(36.4 \pm 22.4 \mathrm{~g})$ was affected by the municipality $(P<0.001)$, but not by the $\mathrm{LW}$ of the $\mathrm{BH}(P>0.05)$. Commercial feed $(8.1 \pm 6.0 \mathrm{~g})$, grains: maize and sorghum $(13.9 \pm 13.5 \mathrm{~g})$ kitchen waste $(1.5 \pm$ $2.9 \mathrm{~g})$, herbaceous $(0.6 \pm 0.9 \mathrm{~g})$ and insects $(0.3 \pm 0.7 \mathrm{~g})$ were found in the crop. According to the commercial feed (COF) component, two feeding systems (FS) were identified: traditional FS, without COF and nontraditional FS, with COF. The diets of both FS were similar $(P>0.05)$ in nutritional composition and do not meet the nutritional requirements of the hens. The LW $(1.567 \pm 0.316 \mathrm{~kg})$ and EW $(51.3 \pm 1.0 \mathrm{~g})$ of the BH cannot be completely attributed to the diet consumed during the rainy season.

Key words: backyard fowl, rural poultry, rural poultry feed.
\end{abstract}

RESUMEN. El objetivo del estudio fue determinar el efecto de la dieta sobre el peso vivo (PV) y peso del huevo (Phvo) de las gallinas de traspatio (GT) durante la época de lluvias en la región Bajío del estado de Michoacán, México. Se muestrearon 17 municipios, en donde se capturaron y se pesaron $101 \mathrm{GT}$ (seis/municipio) y se recolectaron y pesaron 101 huevos (seis/municipio). Se extrajeron, postsacrificio, los buches de las gallinas capturadas, cuyo contenido orgánico/buche (COB) fue clasificado y pesado por componentes, para posteriormente realizar el análisis bromatológico. La información se analizó mediante modelos lineales generalizados y las diferencias entre municipios se obtuvieron por la metodología de medias de mínimos cuadrados. El peso del COB $(36,4 \pm 22,4 \mathrm{~g})$ fue afectado por el municipio $(P<0,001)$, mas no por el PV de GT $(P>0,05)$. En COB se encontró: alimento comercial $(8,1 \pm 6,0 \mathrm{~g})$, granos: maíz y sorgo $(13,9 \pm 13,5 \mathrm{~g})$, desperdicios de cocina $(1,5 \pm 2,9 \mathrm{~g})$, herbáceas $(0,6 \pm 0,9 \mathrm{~g})$ e insectos $(0,3 \pm 0,7$ g). De acuerdo con el componente alimento comercial (AC) se identificaron dos sistemas de alimentación (SA): SA tradicional, sin AC y SA no tradicional, con AC. Las dietas de ambos SA fueron similares $(P>0,05)$ en composición nutrimental y no cumplen con los requerimientos nutricionales de estas aves. El PV $(1,567 \pm 0,316 \mathrm{~kg})$ y el Phvo $(51,3 \pm 1,0 \mathrm{~g})$ de las GT no pueden ser completamente atribuidos a la dieta consumida durante la época de lluvias.

Palabras clave: alimentación avícola rural, ave de corral, avicultura rural.

\section{INTRODUCTION}

According to FAO (2012), backyard poultry farming in Mexico and other emerging or underdeveloped countries, have serious problems in terms of increasing production efficiency. The main difficulty, according to Hernandez et al (2011), is that the nutritional requirements of the backyard hens $(\mathrm{BH})$ are not established which implies real challenges due to the variability in hen nuclei genetics (Gallus gallus domesticus), environment, health and inputs (products and agricultural sub-products; as well as

\footnotetext{
Accepted: 31.01.2017.

anstituto de Investigaciones Agropecuarias y Forestales, Universidad Michoacana de San Nicolás de Hidalgo, Morelia, Michoacán, México. ${ }^{b}$ Facultad de Medicina Veterinaria y Zootecnia, Universidad Michoacana de San Nicolás de Hidalgo, Morelia, Michoacán, México.

cFacultad de Agrobiología “Presidente Juárez", Universidad Michoacana de San Nicolás de Hidalgo, Uruapan, Michoacán, México.

*Corresponding author: A Juárez-Caratachea; $\mathrm{km} 9.5$ carretera Morelia Zinapécuaro, Municipio de Tarímbaro, Michoacán, México; aurelianojuarez@hotmail.com
}

herbaceous and insects that the fowls consume themselves) present in each region and each household ${ }^{1}$.

The lack of nutritional information for the $\mathrm{BH}$ nuclei is caused by the characteristics of this system, which in turn make difficult their study. The rural and indigenous families of Mexico developed this type of activity because the investment of money and material resources do not play an essential role, and the available resources of the rural housing and community are sufficient (Gutiérrez et al 2012). Lushmann (1998) observed that the survival and reproduction of the systems are determined not by the environment, but by intrinsic forces rooting in the "motives" of people, while Juarez et al (2008) established that, within the family, the reasons for poultry production are mainly focused on: economic needs, pleasure, tradition and savings, among others ${ }^{2}$ (Aknola and Essien 2011). These

Juárez CA, Ortiz RR, Pérez SER, Gutiérrez VE, Val DA. 2008. Caracterización y modelación del sistema de producción avícola familiar. Livest Res Rural Develop 20. Accessed January 18, 2015 , available at http://www.lrrd.org/lrrd20/2/juar20025.htm

2 Moreki JC, Dikeme R, Poroga B. 2010. The role of village poultry in food security and HIV/AIDS mitigation in Chobe District of Botswana. Livest Res Rural Develop 22. Access February 15, 2015, available at http://www.lrrd.org/lrrd22/3/more22055.htm 
reasons consequently cause the $\mathrm{BH}$ nuclei to show relatively low productive and reproductive levels. Therefore, incorporating feeding techniques and technologies, as well as prevention of diseases and predators is not expected (Mammo and Wude 2011, Yusuf et al 2014).

The main feed resources for $\mathrm{BH}$ are cereal grains (i.e., maize and sorghum), food waste, herbaceous and insects (Huerta et al 2011, Gutierrez et al 2012). However, the quantity and quality of these inputs depends on the availability in the house, season, crop cycle and life cycle of insects and other invertebrates ${ }^{3}, 4$. According to Minh et al (2006) and Reta ${ }^{5}$, the time of the year plays a key role in the feeding of the backyard fowl, because during the rainy season the availability of the diet improves. The rainy season provides better conditions to increase tha population of herbaceous and insects, improving live weight and productive performance which undoubtedly depends on the genotype, age and individual variation between hens (Source et al 2012).

In brief, the characteristics of the poultry production family system hinder the solution to its problems, as established by FAO (2012), and also the implementation of actions to overcome the limitations for its development ${ }^{6}$. Since these production systems are articulated in such a way that the biological component (hen) coexists with the man in a symbiotic relationship, and due to its management, having control on the different biological events that are inherent to the backyard poultry production is difficult ${ }^{1}$; specially regarding nutrition. Therefore, the objective of this study was to evaluate and relate the components of the diet of $\mathrm{BH}$ with live weight and egg weight during the rainy season in the Bajío region of the state of Michoacán, Mexico.
3 Rashid MM, Islam MN, Roy BC, Jakobsen K, Lauridsen C. 2005. Nutrient concentrations of crop and gizzard contents of indigenous scavenging chickens under rural conditions of Bangladesh. Livest Res Rural Develop 17. Accessed February 10, 2015, available at http://www.lrrd.org/lrrd17/2/rash17016.htm

4 Ruiz SC, Salaverría J, Valles C, Yépez, Herrera S. 2008. Comportamiento de gallinas criollas (gen $\mathrm{Na}$ ) en un sistema semilibre y alimentadas con recursos alternativos en Yaracuy, Venezuela. Livest Res Rural Develop 20. Accessed June 12, 2015, available at http:// www.lrrd.org/lrrd20/5/ruiz20066.htm

5 Reta D. 2009. Understanding the role of indigenous chickens during the long walk to food security in Ethiopia. Livest Res Rural Develop 21. Accessed May 12, 2015, available at http://www.lrrd.cipav.org. co/lrrd21/8/dugu21116.htm

6 Badubi SS, Rakereng M, Marumo M. 2006. Morphological characteristics and feed resources available for indigenous chickens in Botswana. Livest Res Rural Develop 18. Accessed March 15, 2015, available at http://www.lrrd.cipav.org.co/lrrd18/1/badu18003.htm

\section{MATERIAL AND METHODS}

\section{RESEARCH LOCATION}

The study was conducted during the rainy season (June-October) in the Bajío region, Michoacán state, Mexico, which is located between the coordinates $20^{\circ}$ $9^{\prime}$ north latitude and $101^{\circ} 43^{\prime}$ west longitude with a height of 1,690 masl. The temperature ranges between 16 and $22{ }^{\circ} \mathrm{C}$ and annual rainfall between 700 and 1000 $\mathrm{mm}$ (INEGI 2014). In this region, 101 family production systems were selected. The municipalities and communities where the systems were selected were determined based on: I) the inventory of the population of $\mathrm{BH}$ and II) quantity of systems per community and municipality. The municipalities analysed were Angamacutiro, Coeneo, Churintzio, Ecuandureo, Huaniqueo, Villa Jiménez, José Sixto Verduzco, Morelos, Numarán, Penjamillo, La Piedad, Panindícuaro, Puruándiro, Zináparo, Zacapu, Santa Ana Maya and Cuitzeo. Six communities were chosen from each municipality, in which the nuclei of backyard poultry production were selected based on: 1) average number of free-range hens (between 17 to 25 fowl/nuclei), 2) housekeeper availability to provide information and 3) a laying hen that could be identified to later collect the egg and capture the hen.

\section{RESEARCH ANIMALS}

With the information provided by the housekeeper, $101 \mathrm{BH}$ were captured and $101 \mathrm{eggs}$ were collected (one per community $=$ six per municipality) during the rainy season (June to October). Twelve BH were obtained per week during 8.5 weeks, between 12:00 and 17:00 hrs, to ensure the crop of the BH had the highest food content. Once the hens were captured, LW and EW were registered. Eggs were not stored for no more than 7 days. The LW and the EW of the BH was determined using a digital scale (Sartorius model BL1500, with a precision of $\pm 1 \mathrm{~g}$ ). The hens were weighed and immediately sacrificed to collect the crops, according to the "Norma Oficial Mexicana" (NOM-003-ZOO-1995) for the humane slaughter of domestic animals.

\section{SAMPLES}

The feeding information of the $\mathrm{BH}$ analysed was obtained by the chemical composition analysis of the crop content $(n=101)$. Once the crop was removed, it was weighed and immediately placed in a plastic bag and identified. The bags were placed in a cooler and transferred to the Food Analysis and Animal Nutrition Laboratory of the Facultad de Medicina Veterinaria y Zootecnia, Universidad Michoacana de San Nicolás de Hidalgo. In the laboratory, the components of the diet found in the crop of each fowl were separated, identified and classified into 5 groups: 
commercial feed (COF), grains (GS), kitchen wastes (KW), herbaceous (HS) and insects (IS). Once classified and identified by crop, they were dehydrated in a desiccation stove (Felisa Oven 292-D) at $65^{\circ} \mathrm{C}$ for $24 \mathrm{hrs}$ to obtain the weight/content as dry matter.

\section{CHEMICAL COMPOSITION ANALYSIS}

The physicochemical determination of the average crop content per municipality was done as follows: $10 \%$ of each component found was used, afterwards the components were mixed and ground in a porcelain mortar to obtain a homogenous mixture. The chemical composition analysis was done with $10 \mathrm{~g}$ of each mixture according to the technique described by AOAC (2005) and dry matter (DM), crude protein $(\mathrm{CP})$, crude fiber $(\mathrm{CF})$, ether extract $(\mathrm{EE})$, ash (A) and nitrogen free extract (NFE) were determined.

\section{STATISTICAL ANALYSIS}

The information gathered served to generate a data base was for statistical analysis using the methodology of categorical models (CATMOD) and general linear models (GLM) SAS Institute (2002). The difference between municipalities was obtained through the method of least square means (LS Means) SAS Institute (2002).

\section{RESULTS}

An important aspect in backyard poultry is the determination of components in the diet of the hen, because under the family production system (FPS) these fowls are mainly free-range, feeding on what the backyard offer plus supplementation (grain and kitchen waste) offered by the owner. However, in this study the composition of the diet of the $\mathrm{BH}$ was determined through the crop content. In this regard, it was found that during the rainy season, the total crop weight (TCW) was $52.7 \pm 25.8 \mathrm{~g}$. as fed (AF), while the organic content of the crop (OCC) was of $36.4 \pm 22.5 \mathrm{~g}$ dry matter basis (DM) (table 1$)$. The average TCW and the OCC values were affected by the municipality $(P<0.001)$ but not by the live weight (LW) of the $\mathrm{BH}(P>0.05)$, which was $1.567 \pm 0.316 \mathrm{~kg}$.

In relation to the $\mathrm{OCC}$ during the rainy season, the following feed inputs and their quantities were found: $8.1 \pm 6.0 \mathrm{~g}$ commercial feed $(\mathrm{COF}), 14.6 \pm 6.5 \mathrm{~g}$ of grain (maize and sorghum) (GS), $2.2 \pm 2.1 \mathrm{~g}$ kitchen wastes $(\mathrm{KW}), 0.7 \pm 0.4 \mathrm{~g}$ of herbaceous (HS) and $0.6 \pm 0.5 \mathrm{~g}$ of insects (IS). Within this feed inputs, COF was found in $41.5 \%$ of the crops analysed and represented $31.4 \%$ of the TCW (table 1).

According to the COF input, the existence of two feeding systems within the FPS analysed was determined: a) traditional feeding system (TFS) and b) nontraditional feeding system (NTFS), because in the latter, COF was found in the crops analysed (figure 1).

Figure 1 shows that the main feed inputs of the diet in the TFS offered by the rural women during the rainy season were maize and sorghum grains $\left(15.2 \mathrm{~g} \mathrm{GT}^{-1}\right)$ and kitchen wastes $\left(2.5 \mathrm{~g} \mathrm{GT}^{-1}\right)$. The $\mathrm{BH}$ had the possibility to complement this diet with insects $\left(0.58 \mathrm{~g} \mathrm{GT}^{-1}\right)$ and herbaceous $\left(0.26 \mathrm{~g} \mathrm{GT}^{-1}\right)$. Regarding the NTFS, the feed inputs offered by the rural women were $\operatorname{COF}\left(8.1 \mathrm{~g} \mathrm{GT}^{-1}\right)$ plus grains $\left(13.9 \mathrm{~g} \mathrm{GT}^{-1}\right)$ and kitchen wastes $\left(1.8 \mathrm{~g} \mathrm{GT}^{-1}\right)$.

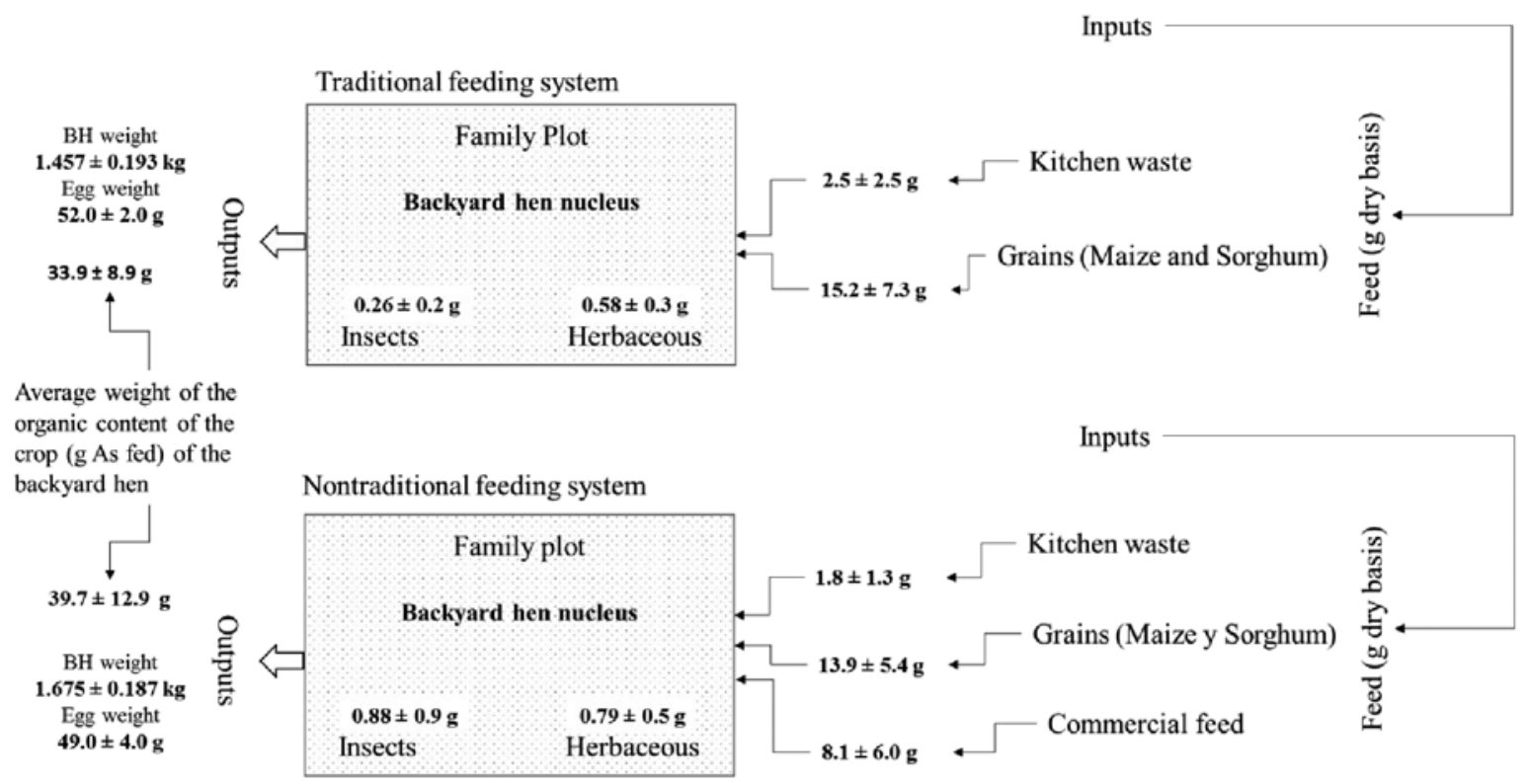

Figure 1. Schematization of two family poultry production systems according to the type and quantity of feed inputs (dry basis) found in the crop of backyard hens in the Bajío region of Michoacán, Mexico, during the rainy season. 
Table 1. Least squares means for the weight of the organic content of the crop and weight ( $\mathrm{g}$ ) of the components of the crop.

\begin{tabular}{|c|c|c|c|c|c|c|}
\hline \multirow{2}{*}{ Municipallity } & \multirow{2}{*}{$\operatorname{OCC}(\mathrm{AF})(\bar{x} \pm)$} & \multicolumn{5}{|c|}{ Weight of component (DM) } \\
\hline & & $\operatorname{COF}(\bar{x} \pm)$ & GS $(\bar{x} \pm)$ & $\mathrm{KW}(\bar{x} \pm)$ & HS $(\bar{x} \pm)$ & IS $(\bar{x} \pm)$ \\
\hline \multicolumn{7}{|c|}{ System with the implementation of COF (NTFS) } \\
\hline Santa Ana Maya & $38.5 \pm 24.6$ & $4.9^{\mathrm{a}} \pm 1.8$ & $13.9^{\mathrm{a}} \pm 10.5$ & $0.4^{\mathrm{a}} \pm 0.1$ & $0.3^{\mathrm{a}} \pm 0.3$ & $2.0^{\mathrm{a}} \pm 0.6$ \\
\hline Cuitzeo & $44.4 \pm 22.0$ & $1.4^{\mathrm{a}} \pm 0.6$ & $13.2^{\mathrm{a}} \pm 13.2$ & $3.9^{\mathrm{a}} \pm 5.7$ & $1.3^{\mathrm{a}} \pm 1.3$ & $0.2^{\mathrm{a}} \pm 0.2$ \\
\hline Coeneo & $18.7 \pm 10.8$ & $3.9^{\mathrm{a}} \pm 0.3$ & $8.3^{\mathrm{a}} \pm 6.3$ & $1.9^{\mathrm{a}} \pm 2.0$ & $0.7^{\mathrm{a}} \pm 1.4$ & $0.2^{\mathrm{a}} \pm 0.1$ \\
\hline Puruándiro & $53.3 \pm 23.2$ & $17.1^{\mathrm{a}} \pm 0.2$ & $14.2^{\mathrm{ab}} \pm 9.1$ & $0.1^{\mathrm{a}} \pm 0.0$ & $0.8^{\mathrm{a}} \pm 0.7$ & $2.4^{\mathrm{a}} \pm 3.1$ \\
\hline Panindícuaro & $50.1 \pm 22.3$ & $16.2^{\mathrm{a}} \pm 0.0$ & $15.2^{\mathrm{ab}} \pm 12.0$ & $1.4^{\mathrm{a}} \pm 1.1$ & $1.5^{\mathrm{a}} \pm 1.8$ & $0.8^{\mathrm{a}} \pm 1.0$ \\
\hline Churintzio & $26.1 \pm 9.3$ & $6.9^{\mathrm{a}} \pm 0.0$ & $8.0^{\mathrm{a}} \pm 4.0$ & $1.9^{\mathrm{a}} \pm 2.1$ & $0.7^{\mathrm{a}} \pm 1.0$ & $0.1^{\mathrm{a}} \pm 0.1$ \\
\hline Numarán & $47.2 \pm 35.5$ & $6.6^{\mathrm{a}} \pm 0.0$ & $24.3^{\mathrm{b}} \pm 30.2$ & $3.1^{\mathrm{a}} \pm 2.2$ & $0.2^{\mathrm{a}} \pm 0.2$ & $0.5^{\mathrm{a}} \pm 0.6$ \\
\hline $\bar{x} \pm$ & $39.7^{\mathrm{q}} \pm 12.9$ & $8.1^{\mathrm{q}} \pm 6.0$ & $13.9^{\mathrm{q}} \pm 5.4$ & $1.8^{\mathrm{q}} \pm 1.3$ & $0.79^{\mathrm{q}} \pm 0.5$ & $0.88^{\mathrm{q}} \pm 0.9$ \\
\hline$\%$ respect to the OCC & & 31.4 & 54.0 & 8.1 & 3.0 & 3.4 \\
\hline \multicolumn{7}{|c|}{ Traditional feeding system (TFS) } \\
\hline Huaniqueo & $22.5 \pm 21.8$ & - & $17.0^{\mathrm{ab}} \pm 14.0$ & $0.1^{\mathrm{a}}$ & $0.4^{\mathrm{a}} \pm 0.4$ & $0.1^{\mathrm{a}} \pm 0.0$ \\
\hline Morelos & $40.4 \pm 26.4$ & - & $19.6^{\mathrm{ab}} \pm 15.1$ & $6.0^{\mathrm{a}} \pm 5.8$ & $0.9^{\mathrm{a}} \pm 0.9$ & $0.1^{\mathrm{a}} \pm 0.0$ \\
\hline Zacapu & $42.8 \pm 18.5$ & - & $32.8^{\mathrm{c}} \pm 17.0$ & $2.3^{\mathrm{a}} \pm 2.4$ & $0.6^{\mathrm{a}} \pm 0.7$ & $0.2^{\mathrm{a}} \pm 0.1$ \\
\hline Ecuandureo & $47.0 \pm 13.9$ & - & $12.5^{\mathrm{a}} \pm 8.4$ & $7.2^{\mathrm{a}} \pm 4.6$ & $1.2^{\mathrm{a}} \pm 0.8$ & $0.4^{\mathrm{a}} \pm 0.3$ \\
\hline José Sixto Verduzco & $24.1 \pm 17.4$ & - & $9.6^{\mathrm{a}} \pm 12.4$ & $4.4^{\mathrm{a}} \pm 5.2$ & $0.5^{\mathrm{a}} \pm 0.4$ & $0.2^{\mathrm{a}} \pm 0.2$ \\
\hline Penjamillo & $30.8 \pm 23.3$ & - & $17.1^{\mathrm{ab}} \pm 18.0$ & $0.2^{\mathrm{a}} \pm 0.1$ & $0.6^{\mathrm{a}} \pm 0.5$ & $0.2^{\mathrm{a}} \pm 0.2$ \\
\hline La Piedad & $27.1 \pm 13.3$ & - & $12.3^{\mathrm{a}} \pm 10.0$ & $1.5^{\mathrm{a}} \pm 1.6$ & $0.2^{\mathrm{a}} \pm 0.2$ & $0.2^{\mathrm{a}} \pm 0.2$ \\
\hline Zináparo & $27.5 \pm 11.6$ & - & $6.9^{\mathrm{a}} \pm 3.4$ & $2.5^{\mathrm{a}} \pm 3.0$ & $0.3^{\mathrm{a}} \pm 0.2$ & $0.1^{\mathrm{a}} \pm 0.0$ \\
\hline Angamacutiro & $36.9 \pm 12.9$ & - & $9.4^{\mathrm{a}} \pm 7.0$ & $1.4^{\mathrm{a}} \pm 2.3$ & $0.2^{\mathrm{a}} \pm 0.2$ & $0.8^{\mathrm{a}} \pm 1.2$ \\
\hline Villa Jiménez & $40.7 \pm 9.6$ & - & $15.2^{\mathrm{ab}} \pm 7.0$ & $0.1^{\mathrm{a}} \pm 0.0$ & $0.9^{\mathrm{a}} \pm 1.4$ & $0.3^{\mathrm{a}} \pm 0.4$ \\
\hline $\bar{x} \pm$ & $33.9^{\mathrm{q}} \pm 8.9$ & $0.0^{\mathrm{z}}$ & $15.2^{q} \pm 7.3$ & $2.5^{\mathrm{q}} \pm 2.5$ & $0.58^{q} \pm 0.3$ & $0.26^{\mathrm{z}} \pm 0.2$ \\
\hline$\%$ respect to the OCC & & 0.0 & 82.1 & 13.5 & 3.1 & 1.4 \\
\hline
\end{tabular}

OCC = Organic Content of the Crop; DM = Dry matter; AF = As fed; COF = Commercial Feed; NTFS = Non-traditional feeding system: with the implementation of COF; TFS = Traditional Feeding System; GS = Grains; KW = Kitchen Waste; HS = Herbaceous; IS = Insects.

$\mathrm{a}, \mathrm{b}, \mathrm{c}, \mathrm{d}=$ Different literals indicate differences $(P<0.05)$ within the column independent of the system.

q, z Different literals indicate differences $(P<0.05)$ within the column between systems.

Nevertheless, the incorporation of $\mathrm{COF}$ in the BH diet, was not reflected in the weight of OCC, since this was the same in both feeding systems $(P>0.05): 33.9 \pm 8.9$ and $39.7 \pm 12.9 \mathrm{~g} \mathrm{AF}$, for TFS and NTFS, respectively.

Maize and sorghum grains represented the greater feed input found in the BH crop in both feeding systems studied: 13.9 and $15.2 \mathrm{~g}$ DM, for NTFS and TFS respectively. This averages were statistically equal $(P>0.05)$. However, in proportion to the OCC, this averages represented 54.0 and $82.1 \%$ of the weight for NTFS and TFS, respectively.

In TFS and NTFS, the BH complemented the diet with the picking of herbaceous and insects. The herbaceous content recovered from the crop was of 0.79 and $0.58 \mathrm{~g} \mathrm{DM}$ for NTFS and TFS, respectively. Values that represented 3.0 and $3.1 \%$ of the OCC weight (table 1). Average weight of insect content was 0.88 and $0.26 \mathrm{~g}$ DM for NTFS and TFS respectively, averages were statistically different $(P<0.05)$ and represented 3.4 and $1.4 \%$ of the OCC weight.

The correlations between the components of the diet and the weight of the OCC determined the following: the grains (sorghum and maize) had the highest correlation with the weight of the OCC $(\mathrm{r}=0.81 ; P<0.001)$. The IS and $\mathrm{KW}$ components were correlated with the weight of OCC of 0.47 and $0.35(P<0.001)$ respectively, whereas the $\mathrm{COF}$ component was not correlated with the weight of OCC $(P>0.05)$ (figure 2). A positive correlation was observed between GS and IS $(\mathrm{r}=0.23 ; P<0.001)$, a negative between GS and COF ( $\mathrm{r}=-0.46 ; P<0.001)$ while a low association between KW and HS ( $\mathrm{r}=0.20 ; P<0.001)$ (figure 2$)$.

The chemical composition of the OCC showed that the nutritional composition of the diet during the rainy season was similar in both systems $(P>0.05)$. The crude protein $(\mathrm{CP})$ content was 12.2 and $12.4 \%$, EE was 4.5 and $4.4 \%$ and CF was 18.6 and $18.3 \%$ for TFS and NTFS, respectively (table 2 ).

The average live weight (LW) of the $\mathrm{BH}(1.567 \mathrm{~kg})$ was affected by the municipality and the feeding system $(P<0.001)$. The average LW for NTFS $(1.675 \mathrm{~kg})$ and TFS $(1.457 \mathrm{~kg})$ were significantly different $(P<0.05)$ from each other (table 3). 


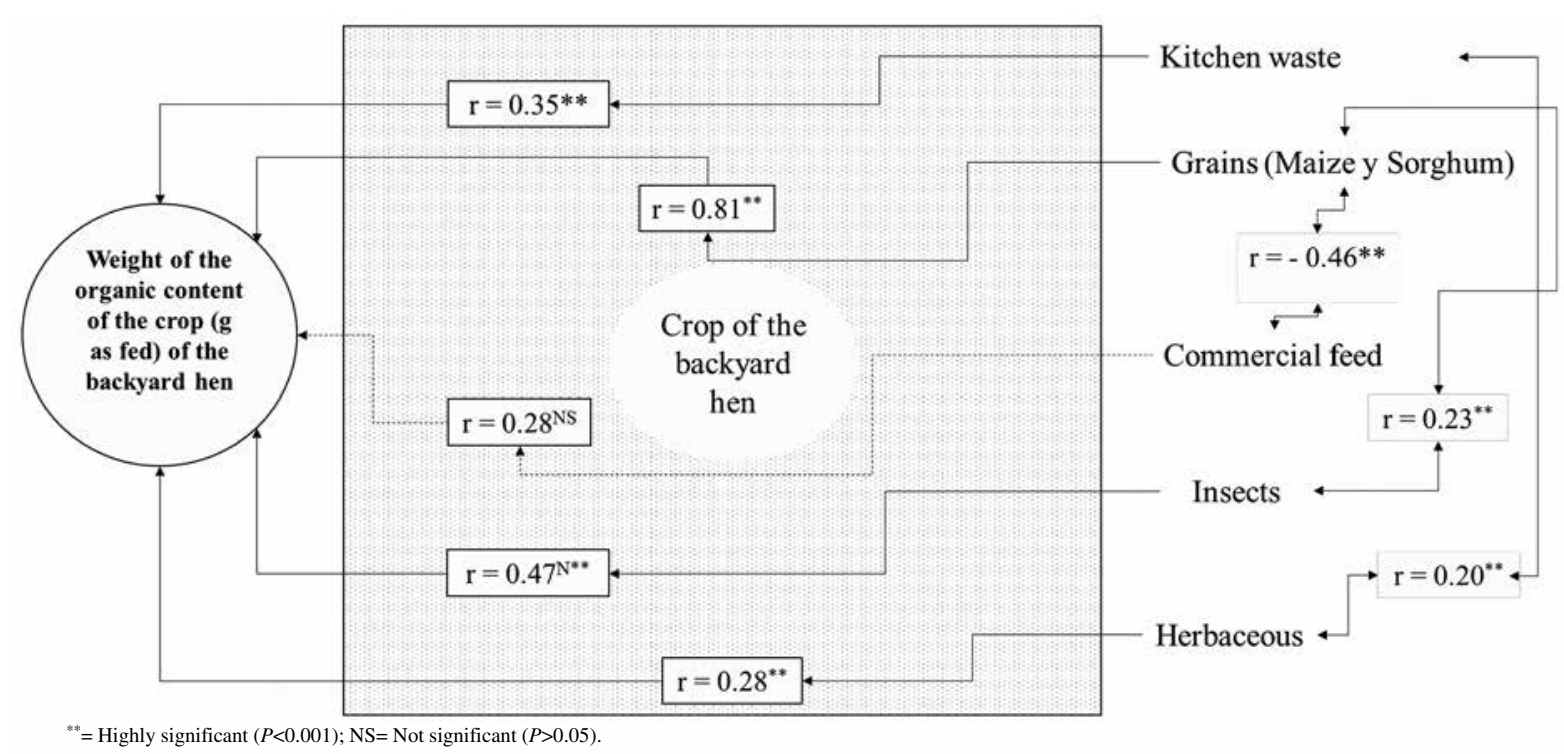

Figure 2. Pearson correlation coefficients between the components of the diet and the weight of the crop content of the backyard hens.

Table 2. Least squares means for the nutritional composition of the crop content ( $88 \%$ dry basis) of the hens according to the feeding system.

\begin{tabular}{lcc}
\hline \multirow{2}{*}{ Variable } & \multicolumn{1}{c}{ TFS } & NTFS \\
\cline { 2 - 3 } & $\bar{x} \pm$ & $\bar{x} \pm$ \\
\hline Dry matter (DM) & $53.2 \pm 9.6$ & $51.6 \pm 5.3$ \\
Ether extract (EE) & $4.5 \pm 2.7$ & $4.4 \pm 0.9$ \\
Crude Protein (CP) & $12.2 \pm 2.2$ & $12.4 \pm 1.7$ \\
Crude Fiber (CF) & $18.6 \pm 3.4$ & $18.3 \pm 1.8$ \\
Nitrogen free extract (NFE) & $59.5 \pm 4.7$ & $57.7 \pm 3.8$ \\
\hline TFS = Traditional feeding system; NTFS = Non-traditional feeding \\
\multicolumn{2}{c}{ system with the implementation of commercial feed. }
\end{tabular}

The average for the $\mathrm{EW}$ of the $\mathrm{BH}$ was $51 \mathrm{~g}$. The average EW was affected by municipality $(P<0.001)$, but not by the feeding systems evaluated (table 3 ). The municipality with the greatest EW $(P<0.05)$ was Numarán $(57.0 \mathrm{~g})$. Nevertheless, according to the municipalities evaluated, it was observed that the average $\mathrm{EW}$ of the $\mathrm{BH}$ ranged from 45.0 to $57.0 \mathrm{~g}$; a difference of $12.0 \mathrm{~g}$ between the lightest and the heaviest egg (table 3 ). The lowest EW (45 g) was observed in the municipalities where less COF was found in the crops (table 1). In the municipalities where the TFS prevailed, the EW was greater $(P<0.05)$ even when the LW of the BH of this municipalities was lowest (table 3 ).

\section{DISCUSSION}

The feed content present in the crop of the BH is definitely key in the determination of not only the components of the diet, but also the nutritional composition because in the family poultry production system it is difficult to establish the quantity and nutritional quality of the feed consumed by this type of fow $1^{1,4}$. Therefore, to determine quantity and quality of the feed consumed by the BH it is necessary to obtain the feed directly from the crop, since the components of the diet are linked to the economic circumstances of the producer, the agro-ecological conditions of the region, the time of year and time of sampling ${ }^{4,5}$. In this sense, the TCW of the $\mathrm{BH}$ found during the rainy season (table 2) were superior to the reported values by Goromela et al (2008), Momoh et al (2010) and Rashid et $a l^{3}$ who found TCW of $28.4,29.8$ and $15.2 \mathrm{~g}$, respectively.

An important element for the TCW is its organic component. In agreement with current results, Goromela et al (2008) and Ruiz et $a l^{4}$ found that cereal grains and kitchen waste are the major components of the OCC of the BH. Nonetheless, Momoh et al (2010) found that kitchen waste is the main component (37.9\%) of the diet of $\mathrm{BH}$, followed by maize and sorghum $(23.3 \%)$, whereas the herbaceous and insects collected in the family backyard represented 9.2 and $7.9 \%$, respectively. In this study, the OCC during the rainy season contained between 3.0 and $3.1 \%$ of insects (mainly R larvae) in the municipalities of Puruándiro and Santa Ana Maya, respectively. This result could be ascribable to municipalities having a vocation for the production of pigs and cattle (INEGI 2016). The manure produced by these species are favorable for incubation and nutrition of the larvae (Arango et al 2004).

On the other hand, the quantity and quality of the herbaceous and insects, which are a source of protein and energy useful for the fowl, are subject to the agro-ecological conditions of the rural communities ${ }^{5}$. According to Ponte et al (2008) and Huerta et al (2011), the consumption of herbaceous sources must not exceed $10 \%$ since an 
Table 3. Least squares means for live weight and egg weight of the backyard hens $(n=101)$ during the rainy season.

\begin{tabular}{|c|c|c|}
\hline \multirow{2}{*}{ Municipallity } & Live weight $(\mathrm{Kg})$ & Egg weight $(\mathrm{g})$ \\
\hline & $\bar{x} \pm$ & $\bar{x} \pm$ \\
\hline \multicolumn{3}{|c|}{ System with the implementation of COF (NTFS) } \\
\hline Santa Ana Maya & $1.931^{\mathrm{a}} \pm 0.412$ & $45.0^{\mathrm{a}} \pm 1.0$ \\
\hline Cuitzeo & $1.681^{\mathrm{b}} \pm 0.233$ & $45.0^{\mathrm{a}} \pm 1.0$ \\
\hline Coeneo & $1.360^{\text {cd }} \pm 0.209$ & $45.0^{\mathrm{a}} \pm 2.0$ \\
\hline Puruándiro & $1.839^{\mathrm{ab}} \pm 0.319$ & $50.0^{\mathrm{b}} \pm 1.0$ \\
\hline Panindícuaro & $1.666^{\mathrm{b}} \pm 0.148$ & $50.0^{\mathrm{b}} \pm 1.0$ \\
\hline Churintzio & $1.541^{\mathrm{bc}} \pm 0.508$ & $55.0^{\mathrm{bc}} \pm 1.0$ \\
\hline Numarán & $1.709^{\mathrm{ab}} \pm 0.227$ & $57.0^{c} \pm 2.0$ \\
\hline $\bar{x} \pm$ & $1.675^{1} \pm 0.187$ & $49.0^{1} \pm 4.0$ \\
\hline \multicolumn{3}{|c|}{ Traditional feeding system (TFS) } \\
\hline Zacapu & $1.217^{\mathrm{d}} \pm 0.234$ & $50.0^{\mathrm{b}} \pm 1.0$ \\
\hline Ecuandureo & $1.525^{\mathrm{b}} \pm 0.270$ & $50.0^{\mathrm{b}} \pm 1.0$ \\
\hline José Sixto Verduzco & $1.633^{b} \pm 0.337$ & $50.0^{\mathrm{b}} \pm 2.0$ \\
\hline Penjamillo & $1.177^{d} \pm 0.467$ & $55.0^{\mathrm{bc}} \pm 1.0$ \\
\hline La Piedad & $1.521^{b c} \pm 0.180$ & $55.0^{\mathrm{bc}} \pm 1.0$ \\
\hline Zináparo & $1.721^{\mathrm{ab}} \pm 0.368$ & $55.0^{\mathrm{bc}} \pm 1.0$ \\
\hline Angamacutiro & $1.364^{\mathrm{cd}} \pm 0.481$ & $55.0^{\mathrm{bc}} \pm 1.0$ \\
\hline Villa Jiménez & $1.380^{\mathrm{cd}} \pm 0.173$ & $55.0^{\mathrm{bc}} \pm 1.0$ \\
\hline Huaniqueo & $1.706^{\mathrm{ab}} \pm 0.165$ & $50.0^{\mathrm{b}} \pm 2.0$ \\
\hline Morelos & $1.332^{\mathrm{d}} \pm 0.234$ & $50.0^{\mathrm{b}} \pm 2.0$ \\
\hline $\bar{x} \pm$ & $1.457^{2} \pm 0.193$ & $52.0^{1} \pm 2.0$ \\
\hline
\end{tabular}

$\mathrm{a}, \mathrm{b}, \mathrm{c}, \mathrm{d}=$ Different literals indicate differences $(P<0.05)$ within the column.

$1,2=$ Different numerals indicate differences $(P<0.05)$ between means within the column.

increase above $10 \%$ increases the amount of fiber, which can limit nutrient utilisation, feed efficiency resulting in reduced growth rate.

Thus, the results of this study suggest that during the rainy season $\mathrm{BH}$ feeding does not change, since it is continually based on the use of agricultural products (grains) and the kitchen waste of the rural families, and complemented by the consumption of forages, herbs and insects (Minh et al 2006, Mekonnen et al 2010).

Regarding the nutritional composition of the $\mathrm{BH}$ diet, Rashid $e \mathrm{al}^{3}$, Goromela et al (2008) and Momoh et al (2010) found CP contents of 10.2, 10.1 and $11.3 \%$, respectively, percentages that are lower than the CP values (12.2-12.4\%) in this study (table 2). Slightly higher CP values (12.9 and $15.5 \%$ ) were reported by Mekonnen et al (2010). Even though in the present study the CP values were higher than the ones found by Rashid et $a l^{3}$, Goromela et al (2008) and Momoh et al (2010), the diets analysed are deficient in $\mathrm{CP}$, considering that a $\mathrm{CP}$ reference point for laying hens should be between 16.5 to $17.5 \%$ (Mekonnen et al 2010, Momoh et al 2010). In addition, Juárez et al (2016) found evidence in the introduction of different genotypes, where genetically improved fowl does not necessarily improve productive indicators of the backyard system. For this reason, the $\mathrm{CP}$ content of the diet should be close to the proposed by the NRC (1994) and Pérez (2013).

The COF could have played an important role in the $\mathrm{CP}$ percentage of the $\mathrm{BH}$ diet and was supplied by the housekeeper, in amounts (8.1 $\mathrm{g}$ on average per crop ${ }^{-1}$ $\mathrm{BH}^{-1}$ ) that are not enough to observe an increment in $\mathrm{CP}$ except in the communities of Puruándiro and Panindícuaro, where the COF average in the crop of the $\mathrm{BH}$ was 17.1 and $16.2 \mathrm{~g}$ (table 1 ); or the COF was obtained by the $\mathrm{BH}$ in the pens of other animals (mainly pigs and cattle), and therefore the variability observed in the different systems analysed ranges from 1.4 to 17.1 $\mathrm{g}$ of COF in DM (table 1). This suggests that the NTFS was created circumstantially, given by the access of the $\mathrm{BH}$ to the $\mathrm{COF}$ in pens of other domestic animals (pigs or ruminants) present in the family plot.

Rashid et $\mathrm{al}^{3}$, Goromela et al (2008) and Momoh et al (2010) determined values for EE of 1.4, 5.4 and 5.1\%, respectively. They also determined NFE, with values of 70.0, 54.6 and $49.0 \%$ respectively; $70.0 \%$ of NFE was superior to the determined in the analysed systems (57.5-59.5\%). Regarding the CF of the diet, Momoh et al (2010) found $7.1 \%$ of $\mathrm{CF}$, this percent was higher in comparison with the result obtained in this study (table 2), but higher to 
the suggested by Blanco $7.5 .0 \%$ of $\mathrm{CF}$ is sufficient in the diet of laying hens. But it is necessary to establish that the CF comes mainly from herbaceous sources, which are harvested by the fowl itself.

The LW of the BH observed during the rainy season could have been affected by genetics instead of the nutritional aspects (Martínez et al 2012, Martínez et al 2013), since the nutritional composition of both feeding systems (TFS and NTFS) were the same $(P>0.05)$. Juárez et $a l^{1}$ reported a higher average $\mathrm{LW}$ of $1.750 \mathrm{~kg}$ for the $\mathrm{BH}$ compared to the low $\mathrm{LW}$ values of $\mathrm{BH}$ obtained in this study (table 3). Jerez et al (2009) reported similar weights between 1.4 and $1.7 \mathrm{~kg}$, affected by the genetic group of the hens and the diet they received; this agrees with Galíndez et al (2012) and Lwelamira (2012), who reported that the weight of the hen is affected by genetic, climatic and zootechnical aspects.

The EW values found in this study are similar to those reported by Martínez et al (2012), who found EW of $51 \mathrm{~g}$ for BH fed a diet containing pumpkin seed flour. However, it has been reported ${ }^{1}$ that the $\mathrm{EW}$ for the $\mathrm{BH}$ was of $55 \mathrm{~g}$. A similar average EW of $55 \mathrm{~g}$ was observed in the municipalities of Penjamillo, Churintzio, Zináparo, Angamacutiro and Villa Jiménez (table 3). An inverse relationship was observed between the EW and LW of the BH $(P<0.05)$. This result is consistent with Martínez et al (2013), but in disagreement with Leeson and Summers (2005) who observed that EW increases with LW. Fuente et al (2012) and Pérez (2013) suggested that the EW is not only affected by the diet, but also by other factors such as genotype, age and week of posture of the hens.

According to the crop content of the $\mathrm{BH}$ during the rainy season, two feeding systems could be determined in the FPS analysed: the traditional system, in which the diet is based mainly on cereal grains (maize and sorghum) and kitchen waste, and complemented by insects and herbaceous sources; and the nontraditional feeding system, in which the same components as the TFS are found, plus the commercial feed.

The combination of these feed inputs in both FPS supplied the BH between 12.2 and $12.4 \%$ of CP to TFS and NTFS, respectively. The quantities of COF given or obtained circumstantially (in the pens of other domestic animals) were not sufficient to make a difference in $\mathrm{CP}$ from the TFS.

The LW and EW of the BH cannot be attributed to the diet during the rainy season. The variability in this indicators suggest that they are related to factors like genetics, age and rate of posture of this type of hens. A possible strategy to improve this systems involves to increase the levels of $\mathrm{CP}$ and $\mathrm{EE}$, promoting the production of insects

7 Blanco RJL. 2006. El estudio de la gallina ecológica. Explotaciones Agropecuarias. Escuela de Ing. Técnicas Agrícolas. España; accessed February 26, 2015, available at http://es.calameo.com/ $\mathrm{read} / 00006823886 \mathrm{~d} 0 \mathrm{f} 56987 \mathrm{a} 9$ within the family plot for the consumption of these by the $\mathrm{BH}$ all year round.

\section{ACKNOWLEDGEMENTS}

The authors would like to thank the National Council of Science and Technology (CONACYT) and the Coordination of Scientific Research (CIC-UMSNH) for the funding granted for this research.

\section{REFERENCES}

AOAC, Association of Official Analytical Chemists. 2005. Official Methods of Analysis. 18 ${ }^{\text {th }}$ ed. AOAC International, Gaithesburg, Maryland, USA.

Arango GGP, Vergara RRA, Mejía VH.2004. Análisis composicional, microbiológico y digestibilidad de la proteína de la harina de larvas de Hermetia illuscens L (Diptera: Stratiomyiidae) en AngelópolisAntioquia, Colombia. Rev Fac Nal Agr 57, 2491-2500.

Akinola LAF, Essien A. 2011. Relevance of rural poultry production in developing countries with special reference to Africa. World's Poult Sci J 67, 697-705.

Egahi JO, Dim NI, Momoh OM, Gwaza DS. 2010. Variations in qualitative traits in the Nigerian local chicken. Int J Poult Sci 9, 978-979.

FAO, Food and Agriculture Organization of the United Nations. 2012. Organización de la Naciones Unidas para la Agricultura y la Alimentación Ganadería mundial 2011 - La ganadería en la seguridad alimentaria. FAO, Roma, Italy.

Fuente MB, Mendoza MGD, Arce MJ, López CC, Ávila GE. 2012. Respuesta productiva de gallinas a dietas con diferentes niveles de proteína. Arch Med Vet 44, 67-74.

Galíndez R, Peña I, Albarran A, Prospert J. 2012. Producción de huevos y fertilidad en cuatro líneas de gallinas reproductoras venezolanas. Rev Fac Agron 38, 123-131.

Goromela EH, Kwakkel RP, Verstegen, MWA, Katule AM. 2008. Effect of season and farming system on the quantity and nutritional quality of scavengable feed resources and performance of village poultry in central Tanzania. J Cell Anim Biol 2, 63-71.

Gutiérrez REJ, Aranda CFJ, Rodríguez VRI, Bolio GME, Ramírez GS, et al. 2012. Factores sociales de la crianza de animales de traspatio en Yucatán, México. Bioagrociencias 5, 21-23.

Hernández ZJS, Pérez R, Silva SE, Hernández JA, González S. 2011. Los traspatios multifuncionales y sustentables: Sus recursos, su ambiente y las amenazas a su permanencia. CONBIAND, San Cristóbal de las Casas, Chiapas, México.

Huerta RS, Magaña SH, Camacho EM. 2011. Aplicación de la técnica de gas in vitro para estimar la digestibilidad de forrajes en aves. $2^{\text {do }}$ Congreso Internacional en Ciencias Veterinarias y Zootecnia, Facultad de Medicina Veterinaria y Zootecnia, Benemérita Universidad Autónoma de Puebla, México, Pp 34.

INEGI, Instituto Nacional de Estadística, Geografía e Informática. 2014. Censo Agropecuario del Estado de Michoacán, México. Gobierno del Estado de Michoacán, Michoacán, México.

Jerez SMP, Reyes SM, Carrillo RJC, Villegas A, Segura CJ. 2009. Indicadores productivos de gallinas criollas en un sistema de producción avícola alternativo en Oaxaca, México. Instituto Tecnológico Agropecuario No 23 de Oaxaca., Centro de Investigación y Graduados Agropecuarios (CIGA), Oaxaca, México.

Juárez CA, Barocio UJN, García VA, Ortiz RR, Vázquez GE. 2016. Efecto del fenotipo (color de plumaje) sobre el peso del huevo y peso vivo de la gallina de traspatio. Arch Med Vet 48, 99-107.

Leeson S, Summers JD. 2005. Comercial Poultry Nutrition. $3^{\text {rd }}$ ed. Nottingham University Press, Nottingham, UK.

Lwelamira J. 2012.Genotype-environmental (G X E) interaction for weights for Kuchi chicken ecotype of Tanzania reared on-station and on-farm. Int J Poult Sci 12, 96-102. 
Mammo M, Wude T. 2011. Phenotypic and genotypic characteristics of indigenous chickens in Ethiopia: A review. Afr J Agric Res 6 , 5398-5404.

Martínez AY, Córdoba LJ, Santana PAA, Martínez YO, Valdivié NMI, et al. 2012. Productividad y calidad del huevo de gallinas con niveles crecientes de harina de semilla de calabaza (Cucurbita maxima). Rev Mex de Cien Pecu 3, 65-75.

Martínez AY, López FY, Martínez YO, Olmo GC, Rodríguez BR.2013. Influencia del peso vivo de gallinas ponedoras White Leghorn (L33) en la producción y calidad del huevo comercial. Rev Granma Cien 17.

Mekonnen H, Mulatu D, Kelay B, Berhan T. 2010. Assessment of the nutritional status of indigenous scavenging chickens in Ada' a district, Ethiopia. Trop Anim Health Prod 42, 123-130.

Minh DV, Lindberg JE, Ogle B. 2006. Effect of season and location on the crop contents of local and improved scavenging hens in northern Vietnam. Trop Anim Health Prod 38, 121-129.
Momoh OM, Egahi JO, Ogwuche PO, Etim VE. 2010. Variation in nutrient composition of crop contents of scavenging local chickens in North Central Nigeria. Agric Biol J North Am 1, 912-915.

NRC, National Research Council. 1994. Nutrient requirements of poultry. $9^{\text {th }}$ ed. National Academy Press, Washington, DC, USA.

Pérez BA. 2013. Influencia de factores nutricionales y de manejo sobre la productividad y la calidad del huevo en gallinas ponedoras rubias. 50 Congreso Científico de Avicultura WPSA-AECA, Lleida, España, Octubre 2013.

Ponte PI, Rosado CM, Crespo JP, Mourao JL, Cheveiro SMA, et al. 2008. Pasture intake the performance and meat sensory attributes of free-range broilers. Poult Sci 87, 71-79.

SAS, Statistical Analysis System. 2000. SAS version 6.0. SAS Institute Inc., Cary, NC, USA

Yusuf SFG, Lategan FS, Masika PJ. 2014. Characterization of indigenous poultry production systems in the Nkonkobe Municipality, Eastern Cape Province South Africa. J Agri Sci 5, 31-44. 